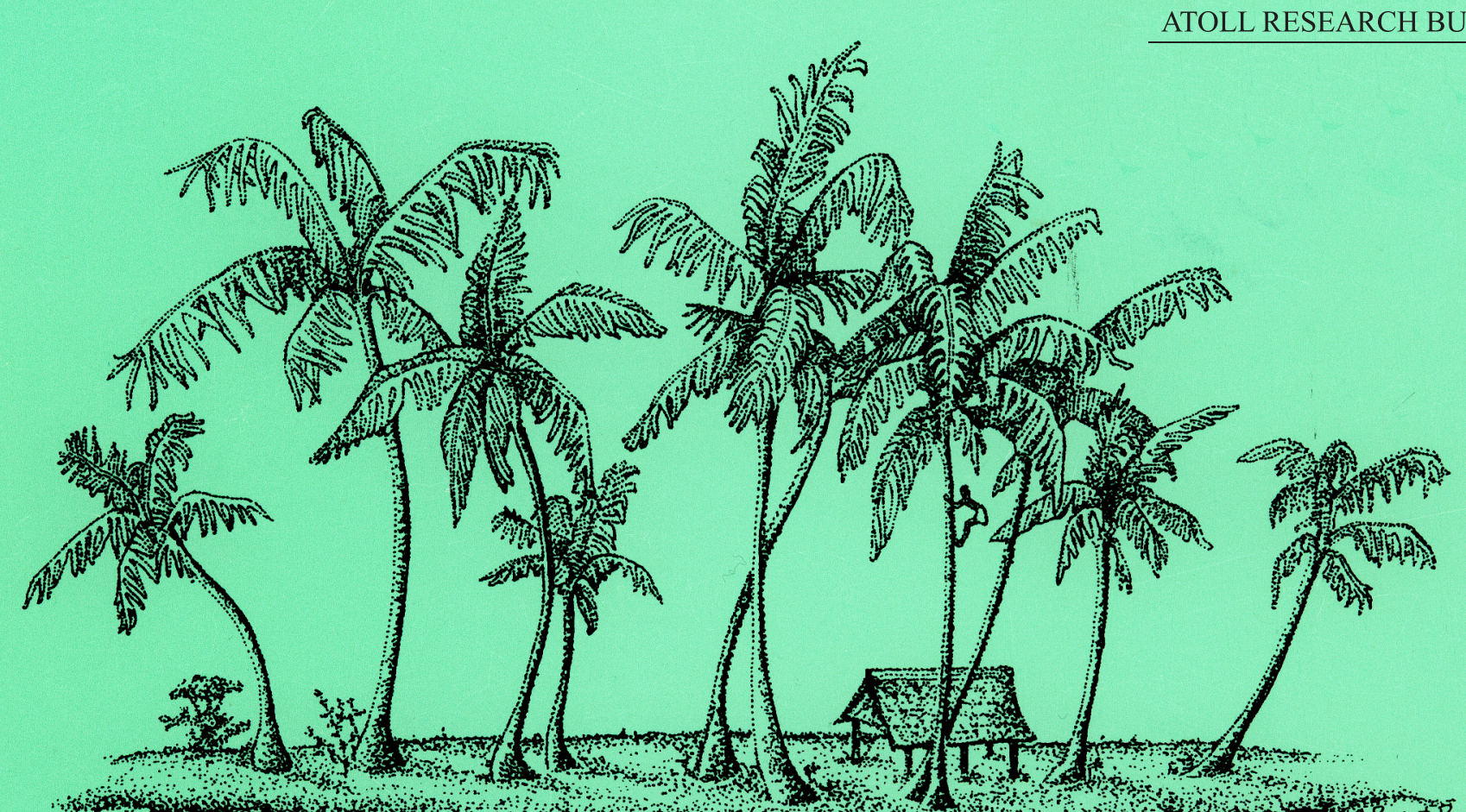

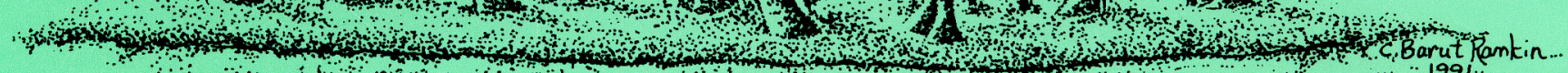
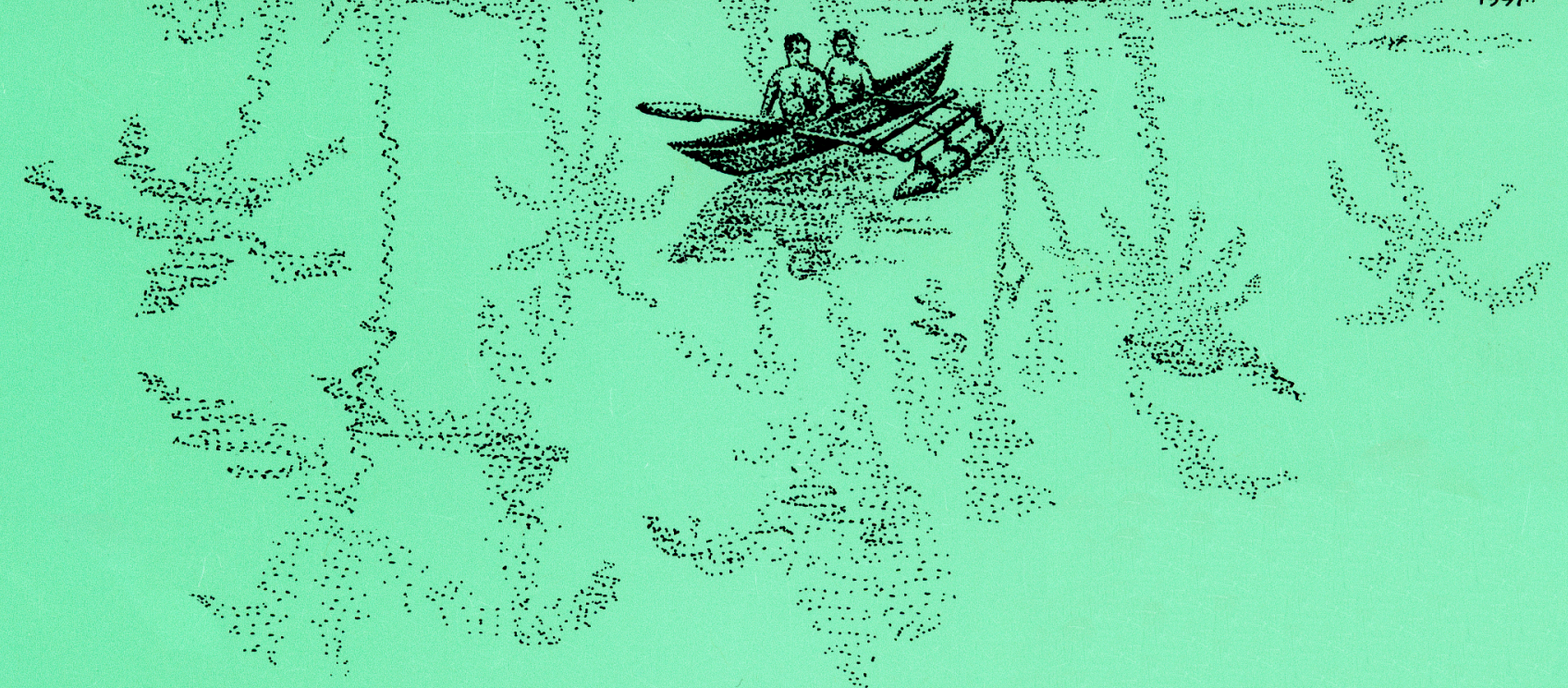

RECOVERY OF MISSING EXPLANATORY NOTES OF THE FIRST GEOLOGICAL MAP

OF FUNAFUTI ATOLL, 1904

Roger F. McLean

(3)

Smithsonian Institution

Scholarly Press
ATOLL

RESEARCH

BULLETIN 


\section{RECOVERY OF MISSING EXPLANATORY NOTES OF THE FIRST GEOLOGICAL MAP OF FUNAFUTI ATOLL, 1904}

Roger F. McLean

Atoll Research Bulletin No. 603 7 July 2014

Smithsonian Institution

Scholarly Press 
All statements made in papers published in the Atoll Research Bulletin are the sole responsibility of the authors and do not necessarily represent the views of the Smithsonian Institution or of the editors of the Bulletin. Articles submitted for publication in the Atoll Research Bulletin should be original papers and must be made available by authors for open access publication. Manuscripts should be consistent with the "Author Formatting Guidelines for Publication in the Atoll Research Bulletin." All submissions to the Bulletin are peer reviewed and, after revision, are evaluated prior to acceptance and publication through the publisher's open access portal, Open SI (http://opensi.si.edu).

Published by SMITHSONIAN INSTITUTION SCHOLARLY PRESS

P.O. Box 37012, MRC 957

Washington, D.C. 20013-7012

www.scholarlypress.si.edu

The rights to all text and images in this publication are owned either by the contributing authors or third parties. Fair use of materials is permitted for personal, educational, or noncommercial purposes. Users must cite author and source of content, must not alter or modify the content, and must comply with all other terms or restrictions that may be applicable. Users are responsible for securing permission from a rights holder for any other use.

ISSN: 0077-5630 (online) 


\title{
RECOVERY OF MISSING EXPLANATORY NOTES OF THE FIRST GEOLOGICAL MAP OF FUNAFUTI ATOLL, 1904
}

\author{
ROGER F. McLEAN ${ }^{1}$
}

\begin{abstract}
Funafuti atoll in the central Pacific was the site of the first deep drilling into a coral atoll. Drilling was carried out during three expeditions in 1896-98, sponsored by the Royal Society, London. Its purpose was purely scientific: to test Charles Darwin's theory of coral atoll formation. Surface geological investigations were also undertaken during the second expedition in 1897, and detailed maps, descriptions and explanatory notes on the 32 islands located on the atoll rim were prepared for publication in the Royal Society's report on The Atoll of Funafuti, published in 1904. However, not all of the island descriptions and explanatory notes that accompanied the final 63 page text and 14 map sheets on the geology of Funafuti Atoll were included in the published work, although this appears not to have been noticed by the volume's editor, Professor T.G. Bonney in London, or by the authors T.W. Edgeworth David and George Sweet in Australia. Lacking are descriptions of the islands on Funafuti's northern and northwestern rim as well as the explanatory notes to accompany five of the 14 map sheets. Searches were undertaken through archives of the expedition in the United Kingdom and Australia in an attempt to uncover the 'missing' material. This archival search met with partial success in the Sir Edgeworth David Papers at Sydney University where a draft manuscript containing 'explanatory notes' on seven islands and five of the 14 map sheets was uncovered. These notes are transcribed in an annex to the present report. The reasons behind the omission of this material in the final publication are not clear, though the archival documentation does provide a fascinating insight into the difficulties associated with scientific expedition publications at the end of the nineteenth century, when editors and authors were separated by large time and space differences, several contributors were involved in map, note and text preparation, and drafts of chapters and illustrations were transported in hard-copy over long distances, such as from Australia to the United Kingdom, as was the case of the Funafuti report.
\end{abstract}

\section{INTRODUCTION}

Funafuti Atoll $\left(8^{\circ} 31^{\prime} \mathrm{S} 179^{\circ} 13^{\prime} \mathrm{E}\right)$ in the central Pacific was one of the two coral atolls well-known to science at the end of the nineteenth century (Figure 1). The other was Cocos (Keeling) Atoll in the Indian Ocean. Both atolls were linked to Charles Darwin and his theory of coral atoll formation that envisaged fringing reefs, barrier reefs and atolls as stages in an evolutionary sequence. The process driving the sequence was gradual subsidence of the volcanic basement on which the reef initially established in combination with vertical reef growth. Cocos (Keeling) was the only atoll that Darwin ever visited, whilst Funafuti became the site selected by the Coral Reef Committee of the Royal Society of London to test his subsidence theory (McLean and Woodroffe, 1994). Drilling in reef substrate was not without its problems and it took three expeditions in 1896, 1897 and 1898 before a satisfactory drill core was recovered. Drilling ceased at a depth of 1114 feet with the core still in shallow-water coral limestone, offering early confirmation of Darwin's subsidence theory.

During the second expedition in 1897, which was organized from the then British Colony of New South Wales, the geology of the islands and adjacent reef flats was mapped by Edgeworth David and George Sweet, assisted by other members of the expedition, notably G.H. Halligan, W. Poole and

\footnotetext{
${ }^{1}$ School of Physical, Environmental and Mathematical Sciences, University of New South Wales - Canberra, Box 7916, Canberra, ACT 2610, AUSTRALIA

Email: r.mclean@adfa.edu.au
} 


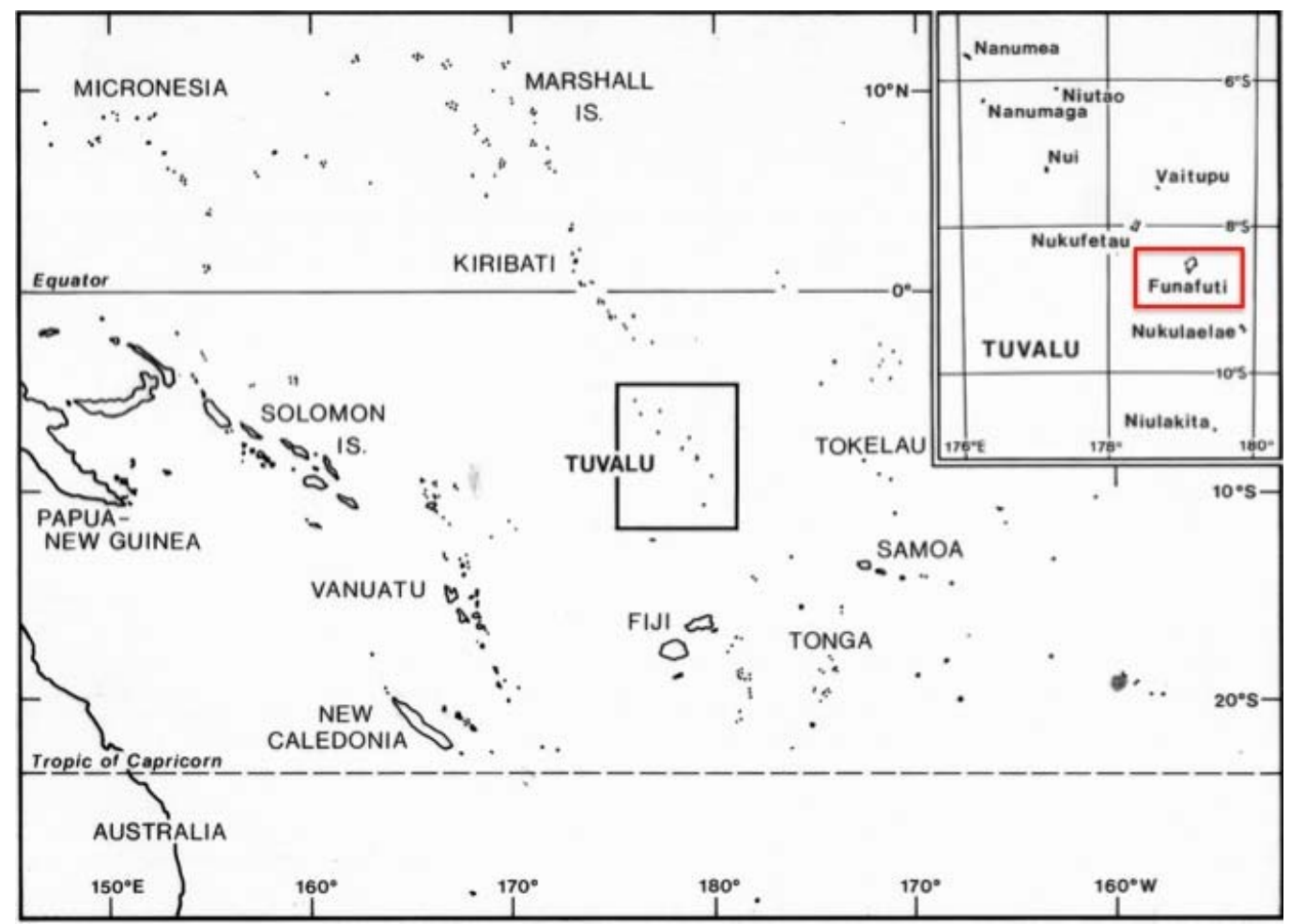

Figure 1. Location of Funafuti Atoll in Tuvalu in the central Pacific. Funafuti is the capital island of Tuvalu (formerly the Ellice Islands).

W.G. Woolnough. David and Sweet's (1904) report on the Geology of Funafuti appears as Section V (pages 61-124) in The Atoll of Funafuti: Borings into a Coral Reef and the Results (Bonney (ed), 1904). The text is accompanied by 14 large scale (1:5000) colored map sheets (Plates 3-16, Sheets $1-$ 14) that include a total of 91 geological sections. The topography was surveyed using either pace or tape for distance and the horizon method or dumpy level for elevation. Maps are presented of 32 islands on the atoll's rim. Authorship of the maps is not consistent. Map Sheets 1-6, 8 and 9 are attributed to Sweet; Sheet 10 to David, Sweet and Woolnough; Sheets 11-13 to David, Sweet and Poole; Sheet 14 to David assisted by Poole, with notes by Sweet; and Sheet 7 to David and Sweet, with additional notes by Poole, Woolnough, Finckh and Halligan.

Further information about the maps is included in two appendices to David and Sweet's text. The first contains a description of the islands on the atoll rim, and the second includes explanatory notes on specific sites identified by alphabetic lettering on the geological maps. However, both published appendices are incomplete: they include only information relating to islands on map sheets 1-6, 8 and 9 that were prepared by Sweet, though there are extensive notes on the main island (Sheet 7). For Sheets 10-14, which cover all islands in the north and northwest of the atoll, there are no descriptions or explanatory notes of lettering, although lettering is included on some, but not all of the island maps. The reason(s) for omission of this information relating to the map sheets where David was senior author is not known, but its absence does present difficulties in interpreting the maps themselves, as well as reducing their value as baselines from which to survey subsequent changes.

\section{THE MAPS, ISLAND DESCRIPTIONS, AND EXPLANATORY NOTES}

David and Sweet's (1904) chapter on the geology of Funafuti Atoll provides the first thorough geological description and interpretation of reef island form and structure of any atoll. Its value lies not only in the text and photographs but also in the island and reef maps and cross-sections supplemented in the detailed island descriptions and annotations to the maps contained in the appendices. In fact, as Spencer et al. (2008) note in a review of coral reefs in a history of the study of landforms and geomorphology: 
"There is no doubt that the maps of Funafuti remain the most comprehensive and detailed illustrations of the surficial morphology of any atoll, notwithstanding surveys by French scientists at Mururoa and Fangatafu and the Americans in the Marshall Islands after World War IF" (Spencer et al., 2008: 887).

On the maps 20 geological units are divided into three broad groupings distinguished by three letters: $\mathrm{O}$ means the rock was formed chiefly on the ocean side of the reef; $\mathrm{L}$ on the lagoon side; and O.L on both the ocean and lagoon sides. Deposit age is denoted by number: higher numbers denote the newer deposits, lower numbers the older. For instance the facies marked O.L.1 is the oldest and forms the hard basement to the islands, while L.9.B is the most recent sand of the lagoon beach. Appendix I is titled Description of Small Islands of the Atoll and as suggested provides descriptive details on the islands included on map sheets 1 to 6 . There is, however, no author attribution to Appendix I. For Appendix II Notes Explanatory of Lettering (other than the symbols in the index) on the Geological Maps, Sweet is identified as the author. The explanatory notes cover Sheets 1 to 9 and provide details of specific sites located on the maps with alphabetic lettering. For instance, on Sheet 1 , that includes the island of Fuagea, the following are two of the notes referring to sites A and B.

"A. Several projecting bosses of upstanding rock are seen here; all those which could be tested were found (except in the case of a few breccia pinnacles) to be Porites. B. Porites block in situ, 7 feet by 4 feet 6 inches high; its top level with high water; lies close up to the base of the sand beach" (David and Sweet, 1904:112).

In the 13 pages of explanatory notes there are 343 entries for 23 islands. There are however no entries for the islands included on Sheets 10 to 14 (Figure 2). Attempts to find the missing notes and descriptions have met with partial success.

\section{SOURCE OF DATA}

Among the Sir T.W. Edgeworth David papers (SU, David, P11, Funafuti) held in the archives of the University of Sydney is a folder titled: "These refer to Sheets 10 to 14 only." This folder contains typed carbon copies of explanatory notes of lettering for islands shown on Sheets 10 to 14, except for the island of Amatuku which does not have any lettering on the published map. Whether these notes were prepared by David or by Sweet is not known for certain, and neither the David Papers at Sydney University nor the Sweet Papers at Museum Victoria shed light on their authorship. However, contrary to the folders title, notes on lettering for the other islands is also included in identical type in the folder, and those notes are associated with map sheets attributed solely to Sweet.

The explanatory notes transcribed here (see Annex 1) can serve as a supplement to Appendix II of David and Sweet's contribution on the geology of Funafuti to make it more complete. The baseline data could also assist future observers in documenting changes to the islands and reefs in the locations covered by sheets 10 to 14 . This was one of the two purposes that the authors set out to achieve when they noted that the detailed geological maps:

“... may prove of use not only in illustrating our present views as to the atoll's structure, but also for later reference, when possible changes on a larger scale in its physical geography and geology are being studied by future observers" (David and Sweet, 1904: 89).

The island order of the original typescript in the University of Sydney archives is not geographically logical (the order is Fuafatu, Fualifeke, Tabuka (Tebuka), Fualopa, Pava, Mulitefala and Tiafualiku (Te Afualiku)) nor is it consistent with the anticlockwise ordering in the published notes and descriptions. Hence, for present purposes the islands have been arranged anti-clockwise, from Mulitefala (Sheet 10) in the northeast to Fuafatu (Sheet 14) in the west (Figure 2). I have also added in brackets after the island name, the map Plate and Sheet number on which the island occurs, 
as well as the author attribution of the relevant map sheet. Brief comments/explanations have been included at the end of some of the island entries.

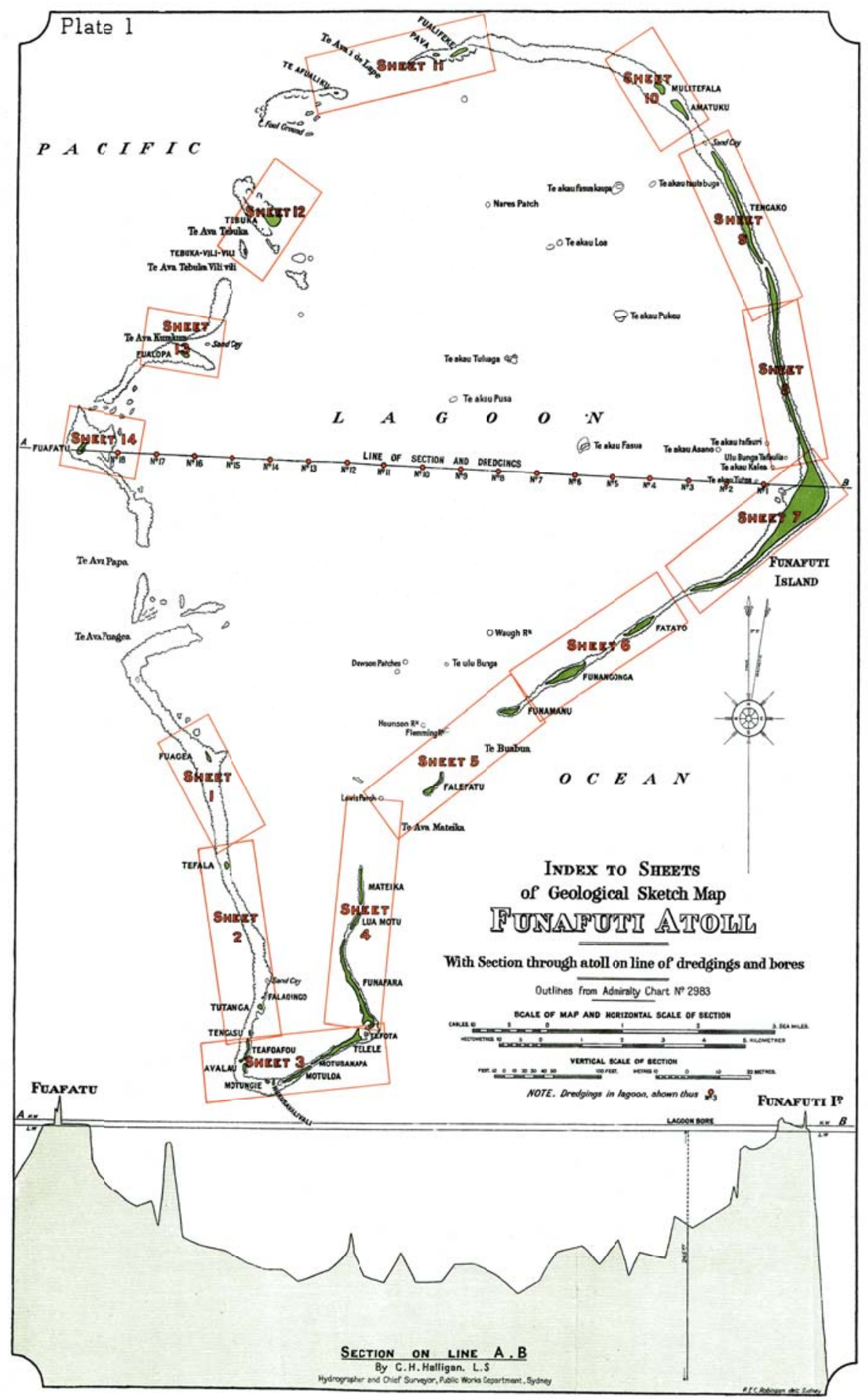

Figure 2. Map index showing location of Map sheets. Sheets 1 to 9 have both descriptions and explanatory notes. Sheets 10 to 14 do not have descriptions and explanatory notes. From David and Sweet (1904), Plate 1. 


\section{DISCUSSION}

It is surprising that the omission of "Notes explanatory of lettering" for Sheets 10 to 14 of the Funafuti report, and descriptions of the islands in the north and northwest of the atoll, has not been commented upon previously. For coral reef science, atoll geology and island geomorphology, Funafuti has great historical significance and to this day the Funafuti boring has been referred to as "an old friend" (Ohde et al., 2002). Moreover, the maps surveyed in 1897 have been used as a baseline to document changes extending over 100 year period for Fongafale Island (Sheet 7) in the east of the atoll (Yamano et al., 2007) and Tepuka (Sheet 12) in the west (Kench et al., 2014)

Second, it is also surprising that the incomplete notes and descriptions were not commented upon by Professor T.G. Bonney who was responsible for editing The Atoll of Funafuti, and even more remarkable that authors David and Sweet did not comment on the missing data. However, nowhere in the David Papers at Sydney University, or in the Sweet Papers at Museum Victoria in Melbourne, is there any evidence that David and/or Sweet saw the draft or proofs of their contributions. In fact, they probably did not, for as Bonney in his preface to the volume notes that:

"Proofs have been submitted to all Authors resident in England, but for misprints to the contributions from Australia I must bear the blame, and trust that any slips on the part of Author or Editor will be leniently judged, for under the circumstances the task has been far from easy" (Bonney, 1904: xiii).

Clearly, editing the volume was not a straight forward task and it took much longer to complete the formal publication (in 1904) than the Royal Society's Coral Reef Committee envisaged, as that committee held its final meeting on 16 December, 1902 (RS CMB/8/435/17).

\section{Problems and Delays with Material from Australia}

There were of course several difficulties in putting together the results of the three expeditions into one publication, including the fact that some of the authors were based in the UK and the others in Australia. Communication by post and person was not rapid, either within Australia or between the UK and Australia. Moreover, in a biography of Edgeworth David, Branagan points out “....all had not gone smoothly for David when working on his reports. His office had been broken into in 1899, and notes and copies of the Funafuti maps stolen, though it was not clear why anyone would want to do that" (Branagan, 2005: 101).

There was also misfortune with the series of colored island maps, geological sections and illustrations that were prepared in Sydney (by Robinson and Co) and were to be taken to London by David himself. Along with most of his clothes, the maps had been stolen from David's railway carriage at Marseilles, France in January 1900, when he was traveling to London with his completed Funafuti manuscript. In the narrative of the second expedition David put it this way: "The unfortunate loss, through theft from a railway carriage in France of some of our geological maps and sections, might have proved serious had it not been for the fact that we had kept copies of them all" (David, 1904: 58). He also noted some earlier escapes for the Funafuti material: "After the maps and sections were finished and on the eve of their transmission to England they narrowly escaped destruction, being about the only material saved from the fire which consumed the premises of the Sydney publishers, Messrs. McCarron and Stewart" (David, 1904: 58).

Shortly after reports of the loss of the maps in France were received in Australia, Sweet became concerned not just about the maps but also about the accompanying text. In a letter to David, Sweet expressed concern about the loss of the maps and was "anxious to know whether the loss included the text" (SU. David. P11/13/ 5/2 Letter Sweet to David, 23 February 1900). There was no clear answer to that query from David, though Branagan (2005: 550) notes that David had to repeat much of his writing, which slowed down the publication process. It is also likely Sweet had to rewrite some of his contributions. In fact it was over a year later that Bonney, who was editing the publication, could write to the leader of the first expedition, Professor Sollas at Oxford: "The plans, sections etc. of the islands, which have been executed under his [David's] eye in Australia, arrived in England about two months ago" (OUM, Sollas Box 1: TGB 1901/6 Bonney to Sollas, 8 August 1901). However, it is not clear whether the explanatory notes for sheets 10 to 14 were included in the package Bonney received. 


\section{Authorship of the Notes: David or Sweet?}

Before these problems arose, when drafts of David and Sweet's report on the geology of Funafuti were going back and forth between Sydney and Melbourne in 1899, the islands in the north and northwest of Funafuti Atoll were being discussed. There was also some urgency in drafting as much of the Australian material as possible, as David was leaving for London in mid-December to report on progress to the Royal Society. By then Sweet had completed most of the plans, sections, notes and descriptions of the islands he was solely responsible for (Sheets 1-6, 8 and 9). Arrangements for maps, notes and descriptions of the other islands (where David was the senior author) were not so clear. In a handwritten letter to David (dated 5 December, 1899) Sweet wrote: "As to the islets in the north of the atoll how do you propose that we should proceed to write about the details of these... You of course have my map notes and some descriptions of them, but that scarcely covers all the ground do you think?" Later in the same letter he specifically refers to the islands that do not have notes in the published volume. "As to map notes of islets from Amatuku to Fuafatu, the maps are themselves with you. I should be pleased if you would send these over as early as possible so that I may proceed with my notes on them for your use" (SU. David, P11/S13/5/2). These are the islands for which there are no published notes.

It is evident that David did return the maps (plans) of the north and northwest islands to Sweet in Melbourne (on 26 December, 1899), and that an earlier draft of his notes on the north and northwest islands was included with the material David took from Australia. This is confirmed in the response to a query from Sweet to Sydney-based surveyor Halligan who wrote back: "With reference to the typed notes the Professor had with him [when he went to London] I can only say that he had your notes (in type) from Fuagea to Mulitefala and that I did not see any others. He did not leave any notes behind him and neither Robinson or I have any copies of them. I expect you will find that he has taken all notes in connection with the work with him" (MV, Sweet Papers folder H-N: Letter Halligan to Sweet, 15 March, 1900).

Perhaps those notes were lost during the incident in France, for their status appears to remain ambiguous, as in March 1900 Sweet's daughter Georgina wrote a long letter to David on behalf of her father indicating Sweet would send cross-sections of the islands Fualopa, Tebuka and Fuafatu as well as any notes of the northern islands to David. She also states that her father "wishes me to remind you that he did carefully pace out and note the particulars of all the north and northwest islands including Pava, Fualifeke and Te Afualiku" (SU David P11/13/5/2: Georgina Sweet to David, 29 March 1900). Three days later Sweet sent to David "the text of the islands Tefota to Fatato and the notes on the islands from Fuagea to Tengako" (SU David P11/13/5/2: Letter Sweet to David, 2 April 1900). (See Figure 2 for the location of the above-named islands.)

It is probable that "the notes on islands from Fuagea to Tengako" referred to in this letter from Sweet are the explanatory notes to Sheets 10 to 14 contained in the David Papers at Sydney University, and reproduced here as Annex 1.

\section{CONCLUSIONS}

Appendix II of David and Sweet's (1904) geology of Funafuti Atoll provides "Notes Explanatory of Lettering on the Geological Maps." However, the notes are incomplete. They refer to 23 of the 32 islands of Funafuti Atoll and only to the islands on those map sheets where George Sweet is sole author. With the exception of the main island (which has six contributors) there are no notes on any islands on map sheets where Edgeworth David is the senior author (map sheets 10 to 14). In the Edgeworth David papers in the archives of Sydney University a folder titled "These refer to Sheets 10 to 14 only" contains typed notes of seven of the islands in the north and northwest of the atoll. These notes (with some annotations) are included here as Annex 1. The original notes are clearly in draft form and can be attributed to Sweet who had responsibility for that section of the report.

Whilst the addition of these notes makes the David and Sweet (1904) contribution more complete, there are still a number of gaps. For example, there are no notes or letters on the map of Amatuku (Sheet 10), and although notes on the island of Fualafeki are included here in Annex 1 there are in fact no letters on the map itself (Sheet 11). Moreover, descriptions of the small islands in the north and 
northwest of Funafuti atoll are also lacking in Appendix 1 of David and Sweet's (1904) publication. These omissions detract from the two purposes of their geological maps, explanatory notes and descriptions, which were to not only illustrate their views on atoll structure and island evolution but also to provide an historical reference point against which later changes in island form and process could be assessed.

\section{ARCHIVAL SOURCES CONSULTED}

IC: Imperial College (University of London) Archives, (FG/2/1-11, Geology Department).

ML: $\quad$ State Library of New South Wales (Mitchell Library) Sir TWE David Papers 1876-937 (ML MSS 3022).

MV: Museum Victoria, Melbourne, Paleontology Department, George Sweet Papers, (File Box, Folders $\mathrm{H}-\mathrm{N}$ ).

NLA: National Library of Australia, Papers of the David Family (MS 8890 and Acc 06/99).

OUM: Oxford University Museum of Natural History, Papers of William Johnson Sollas, 1849-1936 (Boxes 1 and 12).

RS: $\quad$ The Royal Society, London, Archives, Coral Reef Committee of the Royal Society, Coral Minute Book (CMB 8/435).

SU: $\quad$ University of Sydney, Library and Archives, David Papers (SU, David P11/Series 10-15) especially P11/13/5 Research, Funafuti, Correspondence letters written by G. Sweet to TWED (1896-1902). 


\section{ANNEX 1 \\ EXPLANATORY NOTES OF LETTERING, NORTHERN AND NORTHWESTERN ISLANDS}

MULITEFALA (Plate 12, Sheet10 by David, Sweet and Woolnough)

A. Broken masses of breccia hardly covered at half-tide, the remains of an old island.

B. Pool of water.

C. Breccia debris.

D. Breccia and sand, probably a continuance of that further South.

E. Breccia Bank - loose blocks on breccia floor here.

F. Sand above, mantling breccia below.

G. Breccia on O.L.I. platform.

H. Amphistegina abundant in this Foraminiferal sand with some fragments of coral and Nullipore.

I. Pinnacles along here.

Comments:

1) The island of Amatuku is also shown on Plate 12, Sheet 10, but there is no lettering on the map, nor any explanatory notes.

2) Letter $G$ is placed on rock type 0.2.D on the map and not on O.L.1

3) Letter I is not shown on the map, but J (not mentioned above) is shown and its position on rock type O.2.B is consistent with there being 'pinnacles along here'. Note also that the letter I is not included in any of the published explanatory notes, the alphabetic sequence being ...G, H, J, K....

4) Italics added; Nullipore is capitalized in the original.

FUALIFEKE (Plate 13, Sheet 11 by David, Sweet and Poole)

A. $\quad$ Fine sandstone dipping some at $12^{\circ} \mathrm{W}$, and others at S.E.

B. This platform 200 yards out to sea face - 125 yards to low line of pinnacles and corrosion over a rubble covered breccia floor. These old breccia pinnacles and rugged floor are the indirect cause of the presence of this island here, as it breaks the force of the waves before they reach it, and thus shelter it. The platform rises towards the island till close in to the island where it deepens slightly so on the whole greatly breaking the force of the waves, which is still sufficient to throw up the finer fragments.

C. End of sandstone.

D. Fragments of Nullipore and coral etc. resting on the breccia which is here narrow and fragmental and probably is L.2.B.

E. Sandstone dipping $10^{\circ}$.

F. $\quad$ Fine sandstone dipping $9^{\circ}$ N.W. resting on the breccia flat.

G. Outwards from this it was half tide when I was here.

Comments:

1) No lettering is shown on the map of the map of Fualifeke.

2) Plate 13 Sheet 11 also includes the islands of Pava and Te Afualiku.

PAVA (Plate 13, Sheet 11 by David, Sweet and Poole)

A. Some few bosses of Porites whether in situ or not could not be proved.

B. This breccia seems to be newer, it has a sharper dip in parts to, and in other parts from, the passage, some of the finer breccia enclosing Heliopora in situ (see sample).

C. Large bosses of Porites, probably in situ as many are right side up, surrounded by the breccia and more recent conglomerate - some are shifted and embedded in the breccia.

D. Bosses of Porites.

E. Porites probably in situ. Breccia in places with an uncertain dip interbedded with sandstone. 
F. The matted roots here are being undermined and removed.

G. Only very young vegetation in here.

H. Porites continues along here.

TIAFUALIKU (TE AFUALIKU) (Plate 13, Sheet 11 by David, Sweet and Poole)

A. There is probably a newer breccia core to this Hurricane Bank as in one or two places masses are seen to protrude.

B. Several masses of the newer breccia are seen on this N.E. end.

C. There is practically no vegetation on this island except the three trees shown. The High Seas apparently disturb the surface, as the coarse gravel and shingle of which it is composed with some little rubble bears evidence of occasional removal. The waves on this Eastern side end are making breaches in the higher parts.

D. This island is sheltered by the sandstone and newer breccia which act as a breakwater.

E. The island is protected at this South end by brown breccia close up to it and dipping seawards, intercalated with sandstones varying in coarseness till both become bleached by their exposure above High Water.

TABUKA (TEBUKA) (Plate 14, Sheet 12 by David, Sweet and Poole)

A. Sandstone dipping $8^{\circ}$ to passage of consolidated sand.

B. The sandy and fragmental beach here follows the protection offered by the sandstone outcrop which dips from the island.

C. Nullipore forms much of the material of this island. It is found on the beach though apparently in less proportion, the balance being Foraminiferal sand and fragments of coral and shells.

D. Considerable quantities of small nut-sized pumice pebbles, are scattered about the island on and near the surface.

E. Sandstone dipping $10^{\circ} \mathrm{E}$ of consolidated beach sand.

Comments:

1) The small island of Tebuka vili vili is shown on this map sheet, but there are no explanatory notes or cross-sections.

2) On map Sheet 12, Tebuka islet, there is a single cross-section that can be attributed to David, the original survey data being included in the David papers, SU, David, P 11 Ser12/6 Survey results

'Traverse of Tebuka -TWED' (N 232 yds; West 141 yds).

3) Italics added; Nullipore is capitalized in the original.

FUALOPA (Plate 15, Sheet 13 by David, Sweet and Poole)

A. Consolidated sandstone dipping N.E. at $8^{\circ}$.

B. This island is also chiefly Foraminiferal sand and Nullipore with fragments of coral and breccia, and also a few blocks of sandstone and breccia on the surface.

FUAFATU (Plate 16, Sheet 14 by David assisted by Poole. Notes by Sweet)

A. Breccia sheet three inches above High Water.

B. Island 8 feet above High Water, along here.

C, Breccia outcrops here up to a little above High Water.

D. Sand and coral rubble up to 18 inches in length but generally about 6 inches.

E. Very little pure Foraminiferal sand on this island.

F. Foraminiferal sand and fragmental material hardening into an incipient sandstone slightly harder than that at the mangrove swamp.

G. Island suddenly becomes lower through absence of the Hurricane Bank, and we lose the fragment of fresh coral and get breccia and old coral in its place.

H. Porites with other forms in situ here among the breccia. 
I. Mr. Poole's trial pit.

J. $\quad$ Few Porites here.

K. Several Porites and other large corals here, much of it in situ among the breccia.

L. A quantity of small material thrown up at this point chiefly fresh coral, much of it about three inches long. New Heliopora rarely seen in this material.

\section{Comments}

1) Letter I is not shown on the map. The position of 'Mr Poole's trial pit' is at letter J, based on its location on cross-section 2.

2) The above note for letter J above ' Few Porites here' refers to position K on the map. 3) Similarly, note $\mathrm{K}$ refers to $\mathrm{L}$ on the map and note $\mathrm{L}$ refers to the letter $\mathrm{M}$ shown on the northwestern shore of Fuafatu, but is not included in the above notes.

4) Italics added; Nullipore is capitalized in the original. 


\section{REFERENCES}

Bonney, T.G. (ed) 1904. The Atoll of Funafuti. Borings into a Coral Reef and the Results. Being the Report of the Coral Reef Committee of the Royal Society. London: The Royal Society.

Branagan, D. 2005. T.W. Edgeworth David: A Life: Geologist, adventurer, soldier and 'Knight in the old brown hat'. Canberra: National Library of Australia.

David, T.W. Edgeworth. 1904. Narrative of the second and third expeditions. In The Atoll of Funafuti. Borings into a Coral Reef and the Results. Being the Report of the Coral Reef Committee of the Royal Society, ed. T.G. Bonney. pp. 40-60. London: The Royal Society.

David, T.W. Edgeworth, and Sweet, George 1904. The geology of Funafuti Atoll. In The Atoll of Funafuti. Borings into a Coral Reef and the Results. Being the Report of the Coral Reef Committee of the Royal Society, ed. T.G. Bonney. pp. 61-124. London: The Royal Society.

Kench, P.S., J. Chan, S.D. Owen, and R.F. McLean. 2014. The geomorphology, development and temporal dynamics of Tepuka Island, Funafuti Atoll, Tuvalu, Geomorphology. doi:10.1016/j.geomorph.2014.03.043.

McLean, R. F., and C.D. Woodroffe. 1994. Coral atolls, In Coastal Evolution in the Quaternary, ed. R. Carter and C. D. Woodroffe. pp. 267-302. Cambridge: Cambridge University Press.

Ohde, S., M. Greaves, T. Matsuzawa, H.A. Buckley, R. van Woesik, P. A.Wilson, P.A. Pirazzoli and H. Elderfield. 2002. The chronology of Funafuti Atoll: revisiting an old friend. Proceedings of the Royal Society of London. A 458:2289-2306.

Spencer, T., D.R. Stoddart and R, McLean. 2008. Coral Reefs, In The History of the Study of Landform or the Development of Geomorphology: Volume 4: Quaternary and Recent Processes and Forms (1890-1965) and the Mid-Century Revolutions. ed. T.P.Burt, R.J. Chorley, D. Brunsden, N.J. Cox, A.S. Goudie. pp. 863-922. London: Geological Society Publishing House.

Yamano, H., H. Kayanne, T. Yamaguchi, Y. Kuwahara, H. Yokoki H. and H. Shimazaki. 2007.Atoll island vulnerability to flooding and inundation revealed by historical reconstruction: Fongafale Islet, Funafuti Atoll, Tuvalu. Global Planet Change 57: 407-416. 